\title{
Characterization of Cultivable Bacteria Associated with Larval Gut of Field caught Population of Diamondback Moth, Plutella xylostella (Linnaeus)
}

\author{
W. Vijaykumar ${ }^{1 *}$, R. Muthuraju ${ }^{1}$, B. Shivanna ${ }^{2}$, P. Shriniketan, \\ K.V. Vikram and K.S. Sruthy \\ ${ }^{1}$ Department of Agricultural Microbiology, ${ }^{2}$ Department of Agricultural Entomology, \\ University of Agricultural Sciences, Bengaluru-560065, India \\ *Corresponding author
}

A B S T R A C T

\section{Keywords}

Diamondback moth

(DBM), Gut

bacteria,

Morphology,

Biochemical tests,

16S rRNA

Article Info

Accepted:

15 January 2019

Available Online:

10 February 2019

The cole crops like cabbage, cauliflower, broccoli and brussel sprouts etc. are most important vegetables consumed all over the world, among them cabbage and cauliflower are economically vegetables in India. Most of the cruciferous vegetables are vulnerable to many insect pests. The Diamondback moth (DBM), Plutella xylostella Lineaus is the most serious pest in causing economic loss. DBM developed resistant to almost all the synthetic insecticides. Here we collected DBM population from Field of Rattihalli, Haveri district of the state Karnataka, India and reared for one generation. Isolation of cultivable gut bacteria was done from larvae of DBM using agar media and characterized each strain. Some of the strains were gram positive and some were gram negative. Isolate 3 was shown positive result and Isolate 10 was shown negative result for all biochemical tests (IMViC and Catalase). Bacterial genomic DNA were isolated and amplified in PCR with 16S rRNA primers (expected size 1000bp). Eight different bacterial isolates were obtained and identified at genus level such as Pseudomonas otitidis, Dyella japonica, Bacillus sp. Aneurinibacillus aneurinilyticus, Ralstonia solanacearum, Brachybacteria sp., Ralstonia picketti and Kocuria turfanensis. These studies suggest that there were bacterial diversity in DBM and these bacteria helps in development of P. xylostella.

\section{Introduction}

In vegetable production, India is now second largest producer in the world after China with estimated production of about 181 MT during 2017-18 from an area of more than 9.57 million hectares (Third Adv. Est. for Hort. crops). India ranks second in respect of area under cabbage cultivation (400.138 ha) at world level but in respect of productivity it ranks tenth (22.6 MT/ha). One of the serious constraints to the successful production of these crops is ravages of insect pests, especially diamondback moth, Plutella xylostella (Lim et al., 1997). Among the winter vegetables, the cabbage (Brassica oleracea var. capitata Linn.) is extensively cultivated crop because of its nutritional and economical values. It is attacked by a number of insect pests. Diamondback moth ( $P$. xylostella $\mathrm{L})$ is the most destructive insect pest and is the major limiting factor for successful cultivation of cruciferous crops resulting in loss of quality and production. $P$. 
xylostella has national importance on cabbage as it causes $50-80 \%$ annual loss in the marketable yield (Devjani and Singh, 1999). Frequent use of chemical insecticides at higher doses results in depredation of natural enemies and development of insecticide resistance in $P$. xylostella against a wide range of insecticides in different parts of India (Talekar et al., 1990).

The field that has received less attention is the roles that microbes play in protecting insects from toxic plant compounds and insecticides. This is despite the fact that it is known that many microorganisms contain enzymatic degradation mechanisms for a variety of plant secondary metabolites such as terpenes (Marrmulla and Harder, 2014), nicotine and cocaine (Brandsch, 2006) and even phosphorus- or sulfer-containing insecticides (Kerteszet al., 1994). Oftentimes the interaction between microbe and insect are difficult to disentangle, and the relative contribution of insect versus microbial defence mechanism is not yet known. The molecular characterization and identification techniques have improved the analysis of diverse microbial populations (Muyzeret al., 1993).

Studies on lepidopteran gut microbiota suggested that microorganisms provide essential nutrients and play a role in host digestion (Broderick et al., 2004). Priya et al., (2012) isolated and identified Bacillus niabense, Paenibacillus jamilae, Cellulomonas variformis, Acinetobacter schidleri, Micrococcus yunnanesis, Enterobacter sp and Enterococcus cassilifavus from Helicoverpa armigera. Ramesh et al., (2009) characterized gram negative microbes Escherichia coli, Yersinia enterocolitica, Klebsiella, Pneumonia sp. from the gut of silk worm. Madhusudan et al., (2011) isolated Stenotrophomonas sp., Enterococcus casseliflavus, Enterococcus sp.,
Enterococcus gallinarum, Brevundimonas diminuta, Enterococcus faecium, Staphylococcus $\quad$ sp., $\quad$ Pseudomonas aeruginosa, Acinetobacter calcoaceticus, Bacillus subtilis, Rhodococcus sp. from the gut of field collected $H$. armigera larvae. The production of chitinase by gut bacteria from DBM appeared to contribute to host nutrition (Indiragandhi et al., 2007).V

\section{Materials and Methods}

\section{Sample collection and rearing}

The different life stages of DBM such as larvae, pupae and adults were collected from the field of Rattihalli, Haveri district $\left(14.42^{\circ} \mathrm{N}, 75.51^{\circ} \mathrm{E}\right)$ of the state Karnataka, India. In this region, most of the insecticides were used to control this pest but it got resistance to all this insecticides and this region is cabbage growing region of south Karnataka. The populations were reared on mustard (Brassica juncia L.) seedlings in plastic cups containing moistened vermiculite. The individual cups were placed in rearing cages for adult emergence.

\section{Isolation of cultivable bacteria}

The third instar larvae of DBM were starved for 24 hours and surface sterilized with $70 \%$ ethanol for 1 minute followed by $0.1 \%$ sodium hypochlorite for 1 minute, then rinsed with sterile distilled water for 2 to 3 times to remove the external microflora. The homogenized larvae were crushed using pestle and mortar with $1 \mathrm{ml}$ PBS solution $(\mathrm{pH}$ 7.4). The homogenized samples were centrifuged at $2000 \mathrm{rpm}$ for 10 minutes. Serial dilution of samples was made up to $10^{-6}$ dilutions. The aliquot of $1 \mathrm{ml}$ of $4-6$ fold dilutions were plated on media i.e. Nutrient Agar (NA) and Luria Bertani (LB) agar. 100 $\mu l$ of the suspension was inoculated on plates containing media with three replicates. The 
plates were incubated at $28^{\circ} \mathrm{C}$ for 48 hours. After every 24 hours, plates were observed for microbial growth. Based on morphology, selected the colonies and made pure culture. Purification of colonies was done by following quadrant streak plate method. The isolated pure colonies were streaked on NA and LB agar slants and later they were stored in refrigerator for further studies.

\section{Characterization of isolated bacteria}

The preliminary identification of bacterial isolates was based on morphological characteristics, gram staining and biochemical analysis. Bacterial isolates were selected based on morphology like size, shape and colour. Gram staining was done based on standard protocol.

\section{Biochemical characterization of isolated bacteria}

The isolates were subjected to basic biochemical characterization, including IMVIC and catalase reaction. After 48 hours, observations were recorded. IMViC reactions consist of Indole production test, Methyl red and Voges Proskauer test, Citrate test and Catalase test.

The cultures were added in tryptone broth, MR-VP broth, Simmons Citrate Agar and trypticase soy agar contained in test tubes for Indole production test, Methyl Red and Voges Proskauer tests, Citrate utilization test and Catalase test respectively. The all test tubes were incubated for 24-48 hours. After adding the Kovac's reagent, cherry red ring on the top layer of broth indicates the production of indole (positive). For methyl red test, methyl red indicator were added in test tubes containing MR-VP broth, the production of red colour indicates the positive result and having ability to oxidize glucose. For Voges Proskauer, VP reagent 1 and 2 were added, and then pinkish red color appeared which indicates the positive result. For Citrate utilization test, changes in color as an indicator in the media which is from green to blue, indicates positive for this test and for Catalase test, after adding hydrogen peroxide there were formation of bubbles indicates positive result for this test (Benson, 2002).

\section{Molecular identification}

\section{DNA extraction form selected bacterial colonies and gel electrophoresis}

The culturable bacterial isolates were grown in LB broth. The pellets were obtained by centrifugation at $10000 \mathrm{rpm}$ for 1 minute and resuspended in $567 \mu 1$ of TE (1X) buffer. 20 $\mu \mathrm{l}$ of $10 \%$ SDS, $5 \mu \mathrm{l}$ of RNase, $4 \mu \mathrm{l}$ of Proteinase K $(10 \mathrm{mg} / \mathrm{ml})$ and $4 \mu \mathrm{l}$ of lysozyme $(100 \mathrm{mg} / \mathrm{ml})$ were added. The tubes were vortexed 2-3 minutes and kept in hot water bath for 30 minutes at $65^{\circ} \mathrm{C}$. The $100 \mu \mathrm{l}$ of $5 \mathrm{M} \mathrm{NaCl}$ and $80 \mu \mathrm{l}$ of CTAB buffer were added, then incubated in hot water bath for 30 minutes at $65^{\circ} \mathrm{C}$. The equal volume of Chloroform: Isoamyl alcohol (24:1) was added, centrifuged for 5 minutes at 10000 $\mathrm{rpm}$. The supernatant was transferred to a fresh tube. The equal volume of Phenol: Chloroform: Isoamyl alcohol (25:24:1) was added, centrifuged for 5 minutes in 10000 rpm. Supernatant was transferred to a fresh tube and added 1 volume of chilled isopropanol. Incubated the tubes for 10 minutes at room temperature and centrifuged at $10000 \mathrm{rpm}$ for 5 minutes. $1000 \mu \mathrm{l}$ of $70 \%$ chilled ethanol was added to pellet, centrifuged for 1 minute at $10000 \mathrm{rpm}$. The tubes were air dried and dissolved in $80 \mu \mathrm{l}$ of TE buffer.

$1 \%$ agarose gel was prepared by using $1 \mathrm{X}$ TAE buffer and added $2 \mu$ l of ethidium bromide. Comb was placed in boat and gel was poured into it. After solidification, comb 
was removed carefully. The gel was immersed with buffer (1X TAE) in horizontal electrophoresis tank. $2 \mu \mathrm{l}$ DNA samples were mixed with $1 \mu 1$ gel loading dye were loaded into the wells. Then the gel was run at 60 volts for approximately 30 minutes. Gel was viewed under gel documentation unit and was photographed.

\section{Polymerase Chain Reaction (PCR)}

In this study, $16 \mathrm{~S}$ rRNA based approach was used to determine and identify bacterial populations. Nearly full length bacterial $16 \mathrm{~S} \mathrm{r}$ RNA fragments were amplified under conventional PCR conditions $\left(94^{\circ} \mathrm{C}\right.$ for 3 minute, $94^{\circ} \mathrm{C}$ for 30 seconds, $60^{\circ} \mathrm{C}$ for 1 minute, $72^{\circ} \mathrm{C}$ for 1 minute and $72^{\circ} \mathrm{C}$ for 2.5 minutes) by PCR from each representative isolate using primers, Fd1 forward primer (GAGTTTGATCCTGGTCA) and Rp2 reverse primer (ACGGCTACCTTGTTAC GACTT). The 16S rRNA fragment was amplified in thermocycler. Master mix includes all the ingredients except the template DNA (samples) was prepared. Ingredients were added in the following order and kept on ice. Table 1 shows ingredients per reaction mixture. Load the tubes into PCR machine and select the appropriate program for the region being amplified.

\section{Phylogenetics analysis}

The NCBI database (http://www.ncbi.nlm.nih.gov) was BLAST searched for the 16S rRNA gene sequences, which were used to construct a phylogenetic tree by the character-based maximumlikelihood method with molecular evolutionary genetic analysis (MEGA7) software after multiple alignments of the data by CLUSTAL W. The phylogenetic tree was visualized by using tree view. Based on maximum query coverage the bacterial species was identified.

\section{Results and Discussion}

\section{Isolation and characterization gut bacterial isolates}

The totally eight bacterial isolates were obtained based on their morphology among them six bacteria from nutrient agar media and two bacteria from LB media. The bacterial isolates were predominantly circular, raised, smooth, irregular, pasty looking, white in color. Some colonies were slightly dry texture, raised, irregular, concave, yellow color and others were smooth, circular, creamy white color. The four isolates were gram positive and remaining four were gram negative bacteria. Six isolates were rod shaped and two were cocci shaped bacteria (Table 2).

\section{Biochemical characterization of isolated bacteria}

All the bacterial isolates were subjected for biochemical characterization because through the morphology, almost same type of bacterial colonies were analysed. Therefore, Most of the isolates predominantly showed positive results for IMVIC and Catalase test. Among eight isolates, Isolate 3 showed positive result for all the tests and Isolate 10 shown negative result for all the tests. Isolate 6 shown positive results for all tests except catalase test which shown negative result. Isolate 2 and 5 shown positive results for three tests and isolate 1 and 9 shown negative result for three tests as shown in Table 3 and figure 1. For further confirmation and identification of isolates, molecular identification was performed.

\section{Molecular identification of bacterial isolates}

The eight bacteria isolated from DBM larvae were identified and sequenced. The genomic DNA was isolated from eight bacterial isolates. 
Table.1 Preparation of PCR mixture $(50 \mu 1)$

\begin{tabular}{|c|c|}
\hline Master mix & $\mathbf{2 5} \boldsymbol{\mu l}$ \\
\hline Forward primer & $2.5 \mu \mathrm{l}$ \\
\hline Reverse primer & $2.5 \mu \mathrm{l}$ \\
\hline Sterile water & $16.0 \mu \mathrm{l}$ \\
\hline DNA template & $4.0 \mu \mathrm{l}$ \\
\hline
\end{tabular}

Table.2 Morphological features of bacterial isolates of DBM

\begin{tabular}{|c|c|c|c|c|}
\hline SI. No. & Isolates & Colony morphology & $\begin{array}{l}\text { Cell } \\
\text { shape }\end{array}$ & $\begin{array}{l}\text { Gram } \\
\text { reaction }\end{array}$ \\
\hline & NA & & & \\
\hline Isolate 1 & $10^{-3}, \mathrm{R}_{2}, \mathrm{I}_{1}$ & $\begin{array}{l}\text { White, } \\
\text { concave }\end{array}$ & Rod & Negative \\
\hline Isolate 2 & $10^{-4}, \mathrm{R}_{1}, \mathrm{I}_{1}$ & Dark yellow & Rod & Negative \\
\hline Isolate 3 & $10^{-4}, \mathrm{R}_{2}, \mathrm{I}_{1}$ & Dry, dull white & Rod & Positive \\
\hline Isolate 4 & $10^{-6}, \mathrm{R}_{1}, \mathrm{I}_{1}$ & $\begin{array}{l}\text { Raised, irregular, } \\
\text { creamy }\end{array}$ & Rod & Positive \\
\hline Isolate 9 & $10^{-6}, \mathrm{R}_{1}, \mathrm{I}_{2}$ & $\begin{array}{l}\text { Circular, smooth, } \\
\text { yellow }\end{array}$ & Cocci & Positive \\
\hline \multirow[t]{2}{*}{$\begin{array}{l}\text { Isolate } \\
10\end{array}$} & $10^{-5}, \mathrm{R}_{2}, \mathrm{I}_{1}$ & $\begin{array}{l}\text { Smooth, shiny, } \\
\text { circular, } \\
\text { convex, pinkish }\end{array}$ & Cocci & Positive \\
\hline & LB & & & \\
\hline Isolate 5 & $10^{-4}, \mathrm{R}_{1}, \mathrm{I}_{1}$ & Large fluidal white & Rod & Negative \\
\hline Isolate 6 & $10^{-3,} \mathrm{R}_{1}, \mathrm{I}_{2}$ & Dense dark white & Rod & Negative \\
\hline
\end{tabular}

Table.3 Biochemical features of bacterial strains isolated from DBM (Plutella xylostella)

\begin{tabular}{|c|c|c|c|c|c|}
\hline SI. No. & $\mathbf{1}$ & $\mathbf{2}$ & $\mathbf{3}$ & $\mathbf{4}$ & $\mathbf{5}$ \\
\hline Isolate 1 & - & - & + & + & - \\
\hline Isolate 2 & - & + & - & + & + \\
\hline Isolate 3 & + & + & + & + & + \\
\hline Isolate 4 & + & - & - & - & + \\
\hline Isolate 5 & + & + & + & + & - \\
\hline Isolate 6 & + & + & + & + & - \\
\hline Isolate 9 & - & + & - & - & - \\
\hline Isolate 10 & - & - & - & + & - \\
\hline
\end{tabular}

1. Indole production test, 2. Methyl red test, 3. Vogesproskauer test, 4. Citrate utilization test, 5. Catalase test. 
Table.4 Molecular detection and identification of bacterial isolates of Diamondback moth (Plutella xylostella) with percent homology

\begin{tabular}{|c|l|c|c|}
\hline Sr. no. & \multicolumn{1}{|c|}{ Nucleotide sequence identification } & $\begin{array}{c}\text { \% } \\
\text { homology }\end{array}$ & Accession no. \\
\hline Isolate 1 & $\begin{array}{l}\text { Pseudomonas otitidis } \text { strain VKM MO } \\
85\end{array}$ & $99 \%$ & JX852721.1 \\
\hline Isolate 2 & Dyellasp. strain TM-B38 & $99 \%$ & MH8698.1 \\
\hline Isolate 3 & Bacillus sp. 2-8 & $99 \%$ & KJ955376.1 \\
\hline Isolate 4 & Aneurinibacillus sp. strain M-10 & $100 \%$ & KX099269.1 \\
\hline Isolate 5 & $\begin{array}{l}\text { Brachybacterium } \\
\text { KWS1 }\end{array}$ & $92 \%$ & NR-152653.1 \\
\hline Isolate 6 & Kocuriatur fanensis strain 05 & $96 \%$ & MG594807.1 \\
\hline Isolate 9 & Ralstonia solanacearum strain JL1 & $99 \%$ & KF668096.1 \\
\hline Isolate 10 & Ralstonia sp. strain LC & $99 \%$ & MK418966.1 \\
\hline
\end{tabular}

Fig.1 Biochemical characterization of isolated bacteria of DBM (Plutella xylostella)
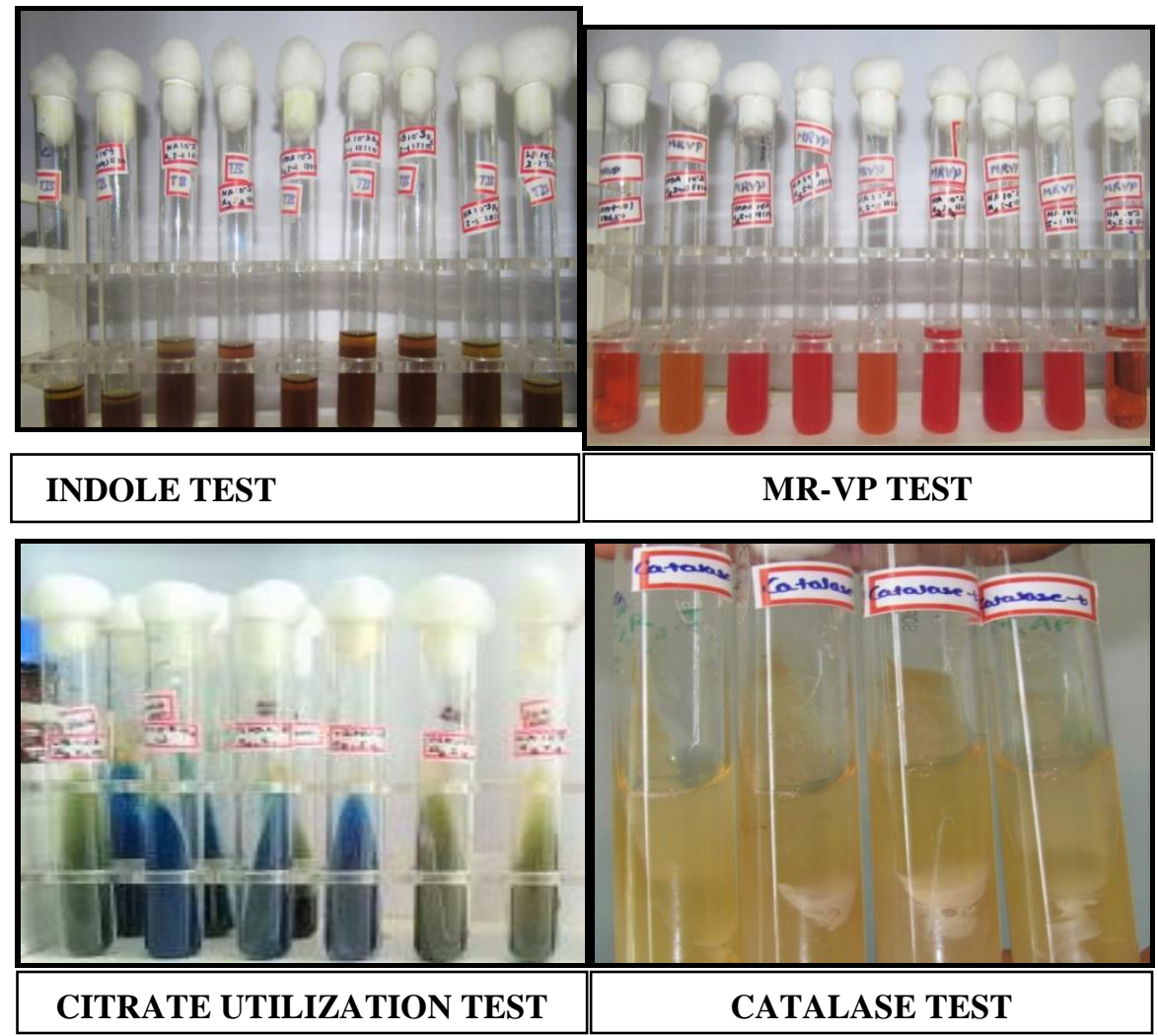
Fig.2 Agarose gel showing amplification of 1000 bp gene corresponding to 16S rRNA, MMarker DNA-1000bp; ISOLATE 1, (2) ISOLATE 2, (3) ISOLATE 3, (4) ISOLATE 4, (5) ISOLATE 5, (6) ISOLATE 6, (7) ISOLATE 9 (8) ISOLATE10

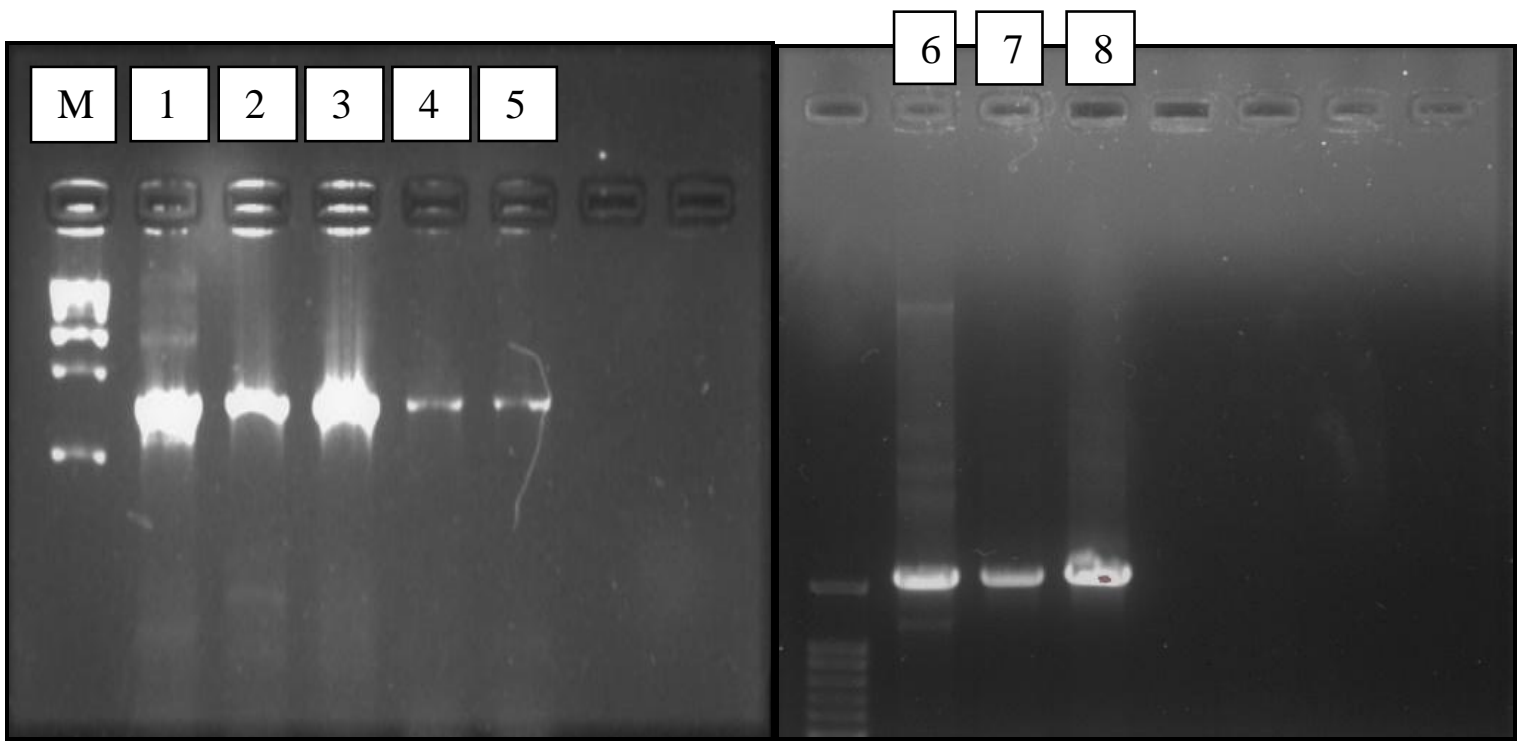

The thick DNA bands (Fig. 2) were visualized on agarose gel under gel documentation photograph represents the presence of DNA and which was subjected to PCR amplification in thermocycler with $16 \mathrm{~S}$ rRNA primers. The amplified products were expected $1000 \mathrm{bp}$ in size. The bacterial isolates were identified as Pseudomonas otitidis, Dyella sp., Bacillus sp, Aneurinibacillus sp., Brachybaccterium aquatium, Kocuria turfanensis, Ralstonia solanacearum and Ralstonia sp. shown in Table 4.

Ramya et al., (2016) isolated culturable gut bacterial flora from both larvae and adults of Diamondback moth and underwent molecular characterization with $16 \mathrm{~S}$ rRNA. They obtained 25 bacterial isolates from larvae $(n=$ $13)$ and adults $(n=12)$ of DBM. In larval gut isolates, gamma proteobacteria was the most abundant (76\%), followed by bacilli (15.4\%). Molecular characterization placed adult gut bacterial strains into three major classes based on abundance: gamma proteobacteria $(66 \%)$, bacilli (16.7\%) and flavobacteria (16.7\%).

In this study, we isolated different bacterial strains from larvae of DBM and selected eight bacterial strains based on their morphology like shape, colour, size etc.

Most of the strains were gram negative bacteria. The biochemical characterization such as IMViC and Catalase test were done. The bacterial cultures were added in respective media or broth, after adding chemical reagents or indicators, there were changes in color of the media or broth and bubble formation in broth indicated positive results for that particular test.

The genomic DNA of all strains was extracted using CTAB method and amplified with PCR. The purified PCR products were sent for sequencing. The sequences obtained were subjected to blast of NCBI. BLAST search analysis of the sequence from bacterial isolates showed $100 \%$ nucleotide identity with 
Aneurinibacillus sp. strain M-10, 99\% nucleotide identity with nucleotide identity with Ralstonia sp. strain LC, Ralstonia solanacearum strain JL1, Bacillus sp. 2-8, Pseudomonas otitidis strain VKM MO 85 and Dyellasp. strain TM-B38, 96\% nucleotide identity with Kocuria turfanensis strain 05 and 92\% nucleotide identity with Kocuria turfanensis strain 05 (Table 4).

Eleftherianos et al., (2013) provided an overview of the effects of endosymbiotic bacteria on the insect immune system as well as on the immune response of insects to pathogenic infections. They discussed potential mechanisms through which endosymbionts can affect the ability of their host to resist an infection. They finally point out unresolved questions for future research and speculate how the current knowledge can be employed to design and implement measures for the effective control of agricultural insect pests and vectors of diseases.

\section{Acknowledgement}

I am grateful to Division of Agricultural Microbiology for giving opportunity to do these researches work and also thankful to Division of Agricultural Entomology and Division of Plant Pathology, University of Agricultural Sciences, Bengaluru, India, for providing me with all the required facilities to complete my research programme.

\section{References}

Benson, H. J., 2002, Microbiological applications. pp. 170-200. Boston, MA: McGraw Hill.

Brandsch, R., 2006, Microbiology and biochemistry of nicotine degradation. Appl. Microbiol. Biotechnol.,69: 493498.

Broderick, N. A., Raffa, K. F., Goodman, R.
M. and Handelsman, J., 2004, Census of bacterial community of gypsy moth larval mid gut by using culturing and culture independent methods. App. Environ. Microbiol., 70: 290-300.

Devjani, P. and Singh, T.K., 1998, Ecological succession of aphids and their natural enemies on cauliflower in Manipur. $J$. Aphidiol., 12(1-2):45-51.

Eleftherianos, I., Atri, J., Accetta, J. and Castillo, J. C., 2013, Endosymbiotic bacteria in insects: guardians of the immune system. Frontiers in Physiology, 4(46): 1-10.

Indiragandhi, P., Anandham, R., Madhaiyan, M., Poonguzhali., KIM, G. H., Saravanan, V. S., and Tonguminsa., 2007, Cultivable bacteria associated with larval gut of prothiofos-resistant, prothiofos -susceptible, and field caught populations of diamondback mothPlutella xylostella and their potential for antagonism towards entomopathogenic fungi and host insect nutrition. J. Appl. Microbiol., 103 (6): 2664-2675.

Kertesz, M. A., Cook, A. M. and Leisinger, T., 1994, Microbial metabolism of sulfur- and phosphorus-containing xenobiotics. FEMS Microbiol. Rev., 15: 195-215.

Lim, G. S., Sivapragasam, A., Loke, M. H., 1997, The management of diamondback moth and other crucifer pests: Proceedings of the Third International Workshop, October 1996, Kuala Lumpur, Malaysia, Malaysian. Agricultural Research Institute, 3-16.

Madhusudan, S., Jalali, S. K., Venkatesan, T., Lalitha, Y. and Prasanna Srinivas, R., 2011, 16S rRNA gene based identification of gut bacteria from laboratory and wild larvae of Helicoverpa armigera (lepidoptera: noctuidae) from tomato farm. The Bioscan., 6(2): 175-183.

Marmulla, R., and Harder, J., 2014, Microbial 
monoterpene transformations-a review. Front Microbiol., 5: 346.

Muyzer, G., Waal, E. C. D., Uitterlinden, A. G., 1993, Profiling of complex microbial populations by denaturing gradient gel electrophoresis analysis of polymerase chain reaction-amplified genes coding for 16S rRNA. Appl. Environ. Microbiol., 59: 695-700.

Priya, N. G., Ojha, A., Kajla, M. K., Raj, A., Rajagopal, R., 2012, Host Plant Induced Variation in Gut Bacteria of Helicoverpa armigera. PLoS ONE,7(1): e30768

Ramesh, G. K., Thangamalar, A., Muthuswami, M. and Subramanian, S., 2009, Characterisation of gram negative bacterial isolates from guts of few multivoltine silkworm breeds. Karnataka J. Agric. Sci.,22(3): 517-518. Ramya, S. L., Venkatesan, T., Kottilingam, S. Murthy, K, S., Jalali, S. K. and Verghese, A., 2016, Detection of carboxylesterase and esterase activity in culturable gut bacterial flora isolated from Diamondback moth, Plutella xylostella (Linnaeus), from India and its possible role in indoxacarb degradation. Brazilian journal of microbiology, 47: 327-336.

Talekar, N. S., Yang, J. C. and Lee, S. T., 1990, Annotated Bibliography of Diamondback Moth, Vol. 2. Shanhua, Taiwan: Asian Vegetable Research and Development Center. 199 pp.

\section{How to cite this article:}

Vijaykumar, W., R. Muthuraju, B. Shivanna, P. Shriniketan, K.V. Vikram and Sruthy, K.S. 2019. Characterization of Cultivable Bacteria Associated with Larval Gut of Field caught Population of Diamondback Moth, Plutella xylostella (Linnaeus). Int.J.Curr.Microbiol.App.Sci. 8(03): 1880-1888. doi: https://doi.org/10.20546/ijcmas.2019.803.223 